\title{
What is the role of Topical Fluoride application in preventing dental erosion?
}

\author{
Avan Mohammed, Karishma Dusara \\ The Royal London Hospital, Institute of Dentistry, Barts \& The London School of Medicine \& Dentistry, Bart's Health NHS Trust
}

\section{Clinical Scenario}

A young female attends the dentist complaining of dental erosion. Her concerns were that the edges of her front teeth appear translucent and have started chipping. She is not complaining of pain or sensitivity but asks the dentist if the use of marketed fluoride-containing toothpastes or mouthwashes can prevent further dental erosion. To find the answer the dentist decided to undertake a literature search.

\section{Introduction}

Dental erosion has been defined as the irreversible loss of hard and soft dental tissues by a chemical process not involving bacteria. ${ }^{1}$ The Adult Dental Health survey of $2009^{2}$ has quoted a rise in moderate tooth wear (including dental erosion) from $11 \%$ to $15 \%$ since 1998. The main age group affected are young adults. The primary reason for this is the increased consumption of carbonated drinks and acidic sweets. ${ }^{3}$ Intrinsic factors such as gastric-oesophageal reflux disease also contribute to dental erosion. Other factors that result in dental erosion include:

- Extrinsic acids such as fruit juices, alcohol, citrus fruits, vinegar, ketchup as well as medications with acidic preparations which include Vitamin C, Iron and Aspirin

- Intrinsic acids due to vomiting, particularly in patients with eating disorders and chronic alcoholism.

It has been recommended that topical fluoride application may prevent the progression of dental erosion. ${ }^{4}$

Clinically, patients with dental erosion have smoothed glazed enamel surfaces and wedged shaped enamel margins. Occlusal erosion often presents with flattening of cusps, cupping and grooving of dental surfaces. Where there is a significant amount of wear, restorations can stand proud of adjacent tooth surfaces with exposed dentine. ${ }^{5}$

Patients with dental erosion may com-

\begin{tabular}{|c|c|c|}
\hline Search number & Search term & Retrieved articles \\
\hline$\# 1$ & Topical Fluoride & 4407 \\
\hline \#2 & Topical Fluorid* & 4033 \\
\hline \#3 & $(\# 1)$ OR (\#2) & 4407 \\
\hline \#4 & Dental erosion & 2695 \\
\hline \#5 & Toothwear & 5599 \\
\hline \#6 & \#5 OR \#4 & 6208 \\
\hline \#7 & Duraphat & 279 \\
\hline \#9 & Fluoride varnish & 716 \\
\hline$\# 11$ & Fluoride mouthwash & 1874 \\
\hline$\# 13$ & Fluoride mouthrinse & 315 \\
\hline \#14 & $\begin{array}{l}\text { (tooth surface loss) AND \#1 Limits: } \\
\text { Randomised Controlled Trial }\end{array}$ & 5 \\
\hline \#15 & $(((\# 1$ OR \#7) OR \#9) OR\#11) OR \#13 & 5930 \\
\hline \#15 & \#6 AND \#15 & 192 \\
\hline \#16 & \#6 AND \#15 Limits: Randomised Controlled Trials & 22 \\
\hline$\# 17$ & Eros* Limits: Randomised Controlled Trials & 1041 \\
\hline \#18 & \#6 OR \#17: Limits: Randomised Controlled Trials & 1139 \\
\hline \#19 & $\begin{array}{l}\text { \#15 AND \#18: Limits: Randomised } \\
\text { Controlled Trials }\end{array}$ & 22 \\
\hline
\end{tabular}

plain of pain, dentine hypersensitivity, functional and aesthetic problems. Dentists are constantly challenged to help manage and effectively treat early signs of erosion.

A dentist noticing an increase in dental erosion in patients can help educate his patients on the relationship between acidic risk factors and erosion. However, changing behaviour is complex and if the acid source is intrinsic or it cannot be identified, it may not be possible to prevent further erosion unaided.

Whilst topical fluoride has been shown convincingly to prevent caries, and though the carious process is a different one from erosive tooth surface loss, it may be reasonable to expect topical fluoride to play a part in the remineralisation or prevention of demineralization. ${ }^{6}$ Topical application of highly concentrated fluoride varnishes
(Duraphat) are often recommended to prevent erosion. ${ }^{7}$ There are however a number of marketed products (toothpastes, mouthwashes and varnishes) such as Sensodyne Pronamel and Colgate ${ }^{\circledR}$ Sensitive Enamel that also claim to help prevent and reduce dental erosion. ${ }^{8}$ Therefore it can be problematic for a General Dental Practitioner to determine the best course of preventative treatment for a patient with or at risk of dental erosion. In order to ascertain this, a critical appraisal of literature was undertaken.

\section{Clinical question}

A PICO format (population/patient/problem, intervention, comparison/control, outcome) was used to structure the following question:

For a patient with or at risk of dental erosion (problem) does the application of topi- 
cal fluoride agents (intervention) compared to no application (comparison) result in reduction of dental erosion (outcome)?

\section{Search strategy}

A search strategy was created on PubMed using the designed PICO question (Table 1). In vitro studies and those using non-human enamel such as bovine teeth were excluded. The search on PubMed included the following key words and their respective MESH terms which included topical fluoride, dental erosion, toothwear, duraphat, fluoride varnish, fluoride mouthwash and fluoride mouthrinse. The search was further restricted to randomised controlled trials and a total of 22 articles were retrieved.

The titles and abstracts of the 22 articles were screened using the exclusion and inclusion criteria above leaving a total of four eligible studies for critical appraisal.

\section{Eligibility and study selection}

Studies were limited to systematic reviews and randomised controlled trials with no language restriction. The inclusion criteria included: in vivo and in situ studies that included the use of human enamel (in the case of an in situ study) and the application of topical fluoride (toothpastes, mouthrinses and varnishes) compared to a placebo dentifrice. However, as the majority of people use fluoridated toothpaste it will be unwise to exclude studies carried out against a background of fluoridated toothpaste and therefore these were also included.

\section{Results}

In vitro studies and studies containing bovine (non-human) enamel were excluded. Only high quality studies were selected - systematic reviews and randomised controlled trials were eligible. A total of 18 studies were excluded after the initial screening process leaving four studies to be reviewed.

One in situ randomised controlled study ${ }^{9}$ confirmed that topical fluoride in the form of a sodium fluoride $(\mathrm{NaF})$ rinse may help remineralise eroded enamel. For 28 days participants wore a fixed appliance made up of an orthodontic bracket and a tooth block. This was bonded to the participant's lower molar tooth. A $3 \mathrm{~mm}$ area on the tooth block was previously subjected to erosive wear by exposing it to $0.3 \%$ citric acid solution ( $\mathrm{pH}$ 3.75) for two hours before it was bonded to the tooth. The participants were given one of four mouthrinses to use: 0 ppm F; 225 ppm F; 225 ppm F + 40 ppm functionalised b-tricalcium phosphate (fTCP); and 450 ppm F. They were instructed to use the mouthrinse twice a day and were given fluoride-free toothpaste to use.

Surface microhardness and transverse microradiography was used to analyse the tooth blocks. The study found that remineralisation of enamel occurred in all four groups. The indent length reduction was greatest in the $225 \mathrm{ppm}$ F plus $40 \mathrm{ppm}$ fTCP group of $41.5 \%$ compared to $1.3 \%$ of the Oppm F mouthrinse. The greatest change in mineral loss was $29.1 \%$ in participants using the 450ppm mouthrinse, which showed remineralisation occurred after 28 days.

Another in situ randomised study ${ }^{10}$ looked at the effect of fluoride varnish on erosive wear during a 15 day period. Participants wore a removable upper appliance with two control enamel blocks and two fluoride varnish coated enamel blocks. The appliances were immersed in Sprite ( $\mathrm{pH}$ 2.81) extra-orally daily and then inserted in the mouth. At the end of the day one control block and one fluoride varnish coated block was brushed with fluoridated toothpaste.

Optical profilometry was used to analyse enamel loss. The study found that the total volume loss of enamel was greater for the non-fluoride varnish treated tooth blocks. The fluoride varnish tooth block had a total enamel volume loss of $0.79 \pm 0.67$ at day 15 and the control tooth block had a total enamel volume loss of $5.53 \pm 2.14$.

Another double-blind three cross over in situ study ${ }^{11}$ looked at the difference between a tin/fluoride mouthrinse and a fluoride only mouthrinse. A small cohort of 24 participants wore a mouth appliance containing enamel blocks for a period of five days. The mouth appliances were immersed for five minutes in $200 \mathrm{ml}$ of demineralisation solution, six times a day. The appliances were rinsed with water and reinserted and participants rinsed once with $10 \mathrm{ml}$ of the respective mouthwash for a period of 30 seconds. Three types of mouthrinses were used in this study; a placebo mouthrinse containing no tin/fluoride, a fluoride only mouthrinse (NaF 500ppm F) and a tin/fluoride mouthrinse. The participants were also provided with a fluoride free toothpaste and a toothbrush to use throughout the period of the study. No other fluoride containing oral products were used.
When compared with the placebo, the NaF mouthrinse reduced substance loss by $19 \%$ in enamel and $23 \%$ in dentin ( $\mathrm{p} \leq$ 0.01 each); and the tin/fluoride containing mouthrinse reduced surface loss by $67 \%$ in enamel and $47 \%$ in dentin ( $\mathrm{p} \leq 0.001$ each). The results showed that the tin/fluoride mouthrinse had better erosion resistance properties over both the placebo and fluoride mouthrinse, only if the human enamel had been subjected to severe erosive wear.

The final randomised crossover in situ study ${ }^{11}$ looked at a small group of ten subjects and enamel wear following exposure to an acidic attack. The subjects wore a mouth appliance containing three human enamel blocks for a period of seven days. The blocks were immersed in a cola drink for five minutes four times a day, before reinsertion. Participants brushed with either placebo toothpaste or fluoride toothpaste $(1,098 \mathrm{ppm}$ F) four times a day for one minute.

The results showed no significant difference in enamel wear between the placebo and fluoride rinse (1,098 ppm F) groups ( $\mathrm{p}$ $>0.05)$, which led to the conclusion that the use of fluoridated toothpaste does not significantly reduce erosion.

\section{Discussion}

The study by Mathews $\mathrm{M}$ et al. ${ }^{9}$ is an in situ study with a short intervention period. Therefore this does not reflect the effect of fluoride on human teeth in vivo over a greater period of time. The $\mathrm{pH}$ of the acid used in this study was 3.75 , which could mean the mouthrinse may not be effective if an acid with a lower $\mathrm{pH}$ were used. There is also a conflict of interest involved in this study, as one of the researchers is involved in investigating the effect of functionalised b-tricalcium phosphate on dental erosion. Therefore some bias may have been involved when presenting the results.

The study by Vieira A et al. ${ }^{10}$ was also an in situ study and had a short intervention period. Participants also only wore the upper removable appliance during working hours and did not eat when they wore the appliance. This does not mimic the extent of continuous erosive attacks on teeth that is usually experienced.

In both the above studies the effects of salivary flow and buffering capacity on erosive wear was not taken into account, 
Table 2. Summary of relevant papers

\begin{tabular}{|c|c|c|c|}
\hline Paper & Study details & Key results/Conclusion & Weaknesses \\
\hline $\begin{array}{l}\text { Mathews M, et. } \\
\text { al (2011) } \\
\text { In situ } \\
\text { remineralisation } \\
\text { of eroded } \\
\text { enamel lesions } \\
\text { by NaF rinses } \\
\text { Setting: } \\
\text { University of } \\
\text { Texas Health } \\
\text { Science Center } \\
\text { at San Antonio, } \\
\text { USA }\end{array}$ & $\begin{array}{l}\text { Design: Randomised, parallel study } \\
\text { Subjects: } 80 \text { subjects ( } 30 \text { male \& } 50 \text { female) with an } \\
\text { age range of } 18-50 \text { year had a bracket with a tooth } \\
\text { block bonded to a lower molar tooth for } 28 \text { days } \\
\text { over four legs. An area on the tooth block had been } \\
\text { exposed to } 0.3 \% \text { citric acid solution (pH 3.75) } \\
\text { extra-orally prior to insertion. } \\
\text { Intervention: Rinsed with } 225 \mathrm{ppm} F, 225 \mathrm{ppm} \\
\mathrm{F}+40 \mathrm{ppm} \text { fTCP (combination of fluoride and } \\
\text { functionalised } \beta \text { tricalcium phosphate) or } 450 \mathrm{~F} \mathrm{ppm} \text {. } \\
\text { Control: fluoride free rinse } \\
\text { Outcomes: } \\
\text { 1. Surface microhardness (SMH) of enamel } \\
\text { 2. Transverse microradiography (TMR) }\end{array}$ & $\begin{array}{l}225 \mathrm{ppm} F \text { plus } 40 \mathrm{ppm} \\
\text { fTCP produced the greatest } \\
\text { indent length reduction of } \\
41.5 \% \text {. } \\
450 \mathrm{ppm} \text { F produced } \\
\text { a statistically greater } \\
\text { percentage change in } \\
\text { mineral loss relative to the } \\
\text { fluoride-free control of } \\
29.1 \% \text { compared to the } \\
\text { other groups. } \\
\text { Adding low levels of fTCP } \\
\text { to a low level fluoride rinse } \\
\text { may provide significant } \\
\text { remineralisation. }\end{array}$ & $\begin{array}{l}\text { All subjects drank fluoridated water } \\
\text { ( } 0.8 \text { ppm F) during the study which } \\
\text { may mean that a greater effect } \\
\text { of fluoride was not obtained as } \\
\text { opposed to a population where } \\
\text { water is not fluoridated. } \\
\text { Study does not state compliance rate } \\
\text { of subjects. } \\
\text { Although the weight of the rinse was } \\
\text { measured before and after study } \\
\text { results of this are not given. } \\
\text { Subjects may have used other oral } \\
\text { hygiene products. } \\
\text { No information given on blinding or } \\
\text { the number of dropouts. } \\
\text { Short intervention period of } 28 \text { days } \\
\text { and therefore the long term effects } \\
\text { of fluoride of erosion and not be } \\
\text { ascertained. }\end{array}$ \\
\hline $\begin{array}{l}\text { Vieira A, et al } \\
\text { (2007) } \\
\text { Inhibition of } \\
\text { erosive wear by } \\
\text { fluoride varnish. } \\
\text { Setting: Faculty } \\
\text { of Dentistry, } \\
\text { University } \\
\text { Medical Centre } \\
\text { Groningen, The } \\
\text { Netherlands }\end{array}$ & $\begin{array}{l}\text { Design: Randomised, single blind } \\
\text { Subjects: } 11 \text { staff and students wore an in-situ } \\
\text { appliance for } 15 \text { days which contained } 4 \text { enamel } \\
\text { blocks. The appliances were worn during working } \\
\text { hours ( } 9.00 \text { am-5.00pm) only. } \\
\text { Intervention: Two enamel blocks were pre- } \\
\text { treated with Fluor Protector a polyurethane-based } \\
\text { varnish containing fluoride (0.1\%) in the form of } \\
\text { difluorosilane. } \\
\text { Erosion of enamel blocks took place daily in-vitro } \\
\text { for } 5 \text { minutes in Sprite (pH } 2.81) \text {. At } 5.00 \text { pm daily } \\
\text { one control block and one fluoride coated block was } \\
\text { brushed with fluoridated toothpaste. } \\
\text { Control: } 2 \text { untreated enamel blocks. } \\
\text { Outcomes: Optical profilometer used to measure enamel } \\
\text { volume loss at day } 5,10 \text { and } 15 \text {. }\end{array}$ & $\begin{array}{l}\text { Enamel volume loss was } \\
\text { least on the fluoride varnish } \\
\text { only block (total enamel } \\
\text { volume loss of } 0.79 \pm 0.67 \\
\text { at day } 15 \text { ) compared to } \\
\text { both controls and fluoride } \\
\text { varnish block that was } \\
\text { brushed. } \\
\text { Total enamel volume loss } \\
\text { for control block was } 5.53 \\
\pm 2.14 \text {. } \\
\text { The fluoride varnish coated } \\
\text { blocks showed less volume } \\
\text { loss than the control } \\
\text { blocks. } \\
\text { Fluoride varnish is effective } \\
\text { in reducing erosion. }\end{array}$ & $\begin{array}{l}\text { Erosion took place extra-orally. } \\
\text { Short intervention period of } 15 \text { days. } \\
\text { Only } 11 \text { subjects in the study. } \\
\text { Participants wore appliances daily for } \\
7 \text { hours only. There were allowed to } \\
\text { remove the appliance for one hour } \\
\text { at lunch. }\end{array}$ \\
\hline $\begin{array}{l}\text { Magalhães A, et } \\
\text { al (2008) } \\
\text { The influence of } \\
\text { residual salivary } \\
\text { fluoride from } \\
\text { dentifrice on } \\
\text { enamel erosion: } \\
\text { an in situ study } \\
\text { Setting: Dental } \\
\text { School. Brazil }\end{array}$ & $\begin{array}{l}\text { Design: Randomised, crossover and double blinded } \\
\text { Subject: } 10 \text { participants (mean age } 24 \text { years) } \\
\text { All subjects had a normal salivary flow rate and lived in } \\
\text { a fluoridated area ( } 0.70 \text { mgF/L) } \\
\text { Intervention: } 60 \text { enamel blocks prepared from } \\
\text { recently extracted impacted human third molars } \\
\text { divided into two groups (A and B) } \\
\text { In each group, participants wore acrylic palatal } \\
\text { appliances, which contained } 3 \text { blocks. } \\
\text { The blocks were immersed in a cola drink for } 5 \\
\text { minutes } 4 \text { times a day. Volunteers brushed their teeth } \\
\text { with one of the toothpastes (containing ( } 1,098 \text { ppm } \\
\text { or F- Free) before returning the appliance into the } \\
\text { mouth and wearing it for } 7 \text { days. } \\
\text { The volunteers were randomly allocated to treatments } \\
\text { and those who used the placebo toothpaste in the } \\
\text { first phase (A) used Fluoride toothpaste in the second } \\
\text { phase (B), and vice versa. } \\
\text { Control: fluoride free toothpaste } \\
\text { Outcome: Enamel wear was determined using } \\
\text { profilometry, microhardness assessment (\%SMHC), } \\
\text { and acid- and alkali-soluble F analysis. }\end{array}$ & $\begin{array}{l}\text { There were no significant } \\
\text { differences ( } p>0.05) \\
\text { between the groups in } \\
\text { respect to the presence of } \\
\text { fluoride in enamel. } \\
\text { The use of fluoridated } \\
\text { toothpaste }(1,089 \mathrm{ppm} \\
\text { F) did not significantly } \\
\text { reduce the wear and the } \\
\% \text { SMHC of eroded enamel } \\
\text { in comparison to the } \\
\text { non-fluoridated toothpaste } \\
\text { ( } p>0.05) \text {. } \\
\text { Results show that residual } \\
\text { salivary fluoride from } \\
\text { toothpaste does not have a } \\
\text { preventive effect to enamel } \\
\text { against erosion }\end{array}$ & $\begin{array}{l}\text { Short intervention period } \\
\text { Insufficient number of subjects to } \\
\text { detect a difference } \\
\text { Patient were not followed up at } \\
\text { home during the study } \\
\text { No mention of diet modification } \\
\text { Subjects live in a fluoridated area }\end{array}$ \\
\hline
\end{tabular}


Table 2. Summary of relevant papers (continued)

\begin{tabular}{|c|c|c|}
\hline $\begin{array}{l}\text { Ganss C, et al } \\
(2010) \\
\text { Efficacy of a } \\
\text { Tin/Fluoride } \\
\text { Rinse } \\
\text { a Randomized } \\
\text { in situ Trial on } \\
\text { Erosion } \\
\text { Setting: Dental } \\
\text { Hospital, } \\
\text { Germany }\end{array}$ & $\begin{array}{l}\text { Design: a prospective randomized double-blind } \\
\text { three-cell crossover in situ study } \\
\text { Subject: persons } 24 \text { (mean age 32) } \\
\text { Intervention: } 432 \text { Enamel and dentin samples were } \\
\text { prepared from freshly extracted previously impacted } \\
\text { human third molars. } \\
\text { Three types of mouthrinses were used : AmF/ } \\
\text { NaF/SnCl } 2 \text { mouthrinse was compared with NaF } \\
\text { mouthrinse ( } 500 \text { ppm F) and a placebo mouthrinse. } \\
\text { The affect was tested on both enamel and dentine. } \\
\text { No other fluoride containing products were used, } \\
\text { participants were give a fluoride free toothpaste. } \\
\text { Mouth appliances were immersed extra-orally in citric } \\
\text { acid for } 5 \text { min, } 6 \text { times a day. Appliances were then } \\
\text { rinsed once with } 10 \text { mL of the respective mouthrinse } \\
\text { for } 30 \text { sec and worn. } \\
\text { Control: Placebo mouthrinse and NaF mouthrinse } \\
\text { Outcome: loss of enamel and dentin was measured } \\
\text { profilometrically }\end{array}$ & $\begin{array}{l}\text { In the placebo group } \\
\text { enamel tissue loss was } \\
28.2 \pm 6.1 \mu \mathrm{m} \text {. The } \mathrm{NaF} \\
\text { mouthrinse led to } 19 \% \\
(22.8 \pm 6.0 \mu \mathrm{m}, \mathrm{p} \leq \\
0.01) \text {. enamel tissue loss } \\
\text { compared with a } 67 \% \text { ( } 9.3 \\
\pm 4.5 \mu \mathrm{m}, \mathrm{p} \leq 0.001) \text { in the } \\
\text { tin/fluoride mouthrinse } \\
\text { In dentine, placebo group } \\
\text { showed } 43.8 \pm 9.2 \mu \mathrm{m} \\
\text { tissue loss compared to } \\
33.7 \pm 6.6 \mu \mathrm{m} \text { in the NaF } \\
\text { group and } 23.2 \pm 6.8 \mu \mathrm{m} \\
\text { in tin/fluoride group. } \\
\text { The tin/fluoride mouthrinse } \\
\text { was significantly more } \\
\text { effective than placebo and } \\
\text { NaF in inhibiting erosive } \\
\text { tissue loss in enamel as well } \\
\text { as in dentin, even under } \\
\text { the severe erosive }\end{array}$ \\
\hline
\end{tabular}

Small number of subjects.

In situ study. as this would have helped remineralisation alongside topical fluoride.

This study by Ganss $\mathrm{C}$ et al. ${ }^{11}$ aimed to investigate the effect of a tin/fluoride and fluoride only mouthrinse under severe erosive conditions, which reflects the possible effects on the dentition of a high risk patient. The outcome of this study therefore showed that both low and high risks patients could benefit from the use of a tin/fluoride mouthrinse. The effects of salivary flow and buffering capacity on erosive wear were not taken into account.

This particular in situ study, (Magalhães A, et al., $)^{12}$ was conducted on a small number of subjects; too small to detect a significant difference in the results. Furthermore, all the participants were living in fluoridated area (0.70 mgF/L). Hence, the study does not take into account populations living in non-fluoridated areas. The concentration of residual fluoride in the saliva was not evaluated as the volunteers conducted the study at home.

In summary, all four studies that were confined to the clinical question addressed in this DEBT had a short intervention period ranging from eight hours to up to 28 days. The total number of participants involved was small, however three of the studies $9,10,11$ showed a statistically significant difference in the outcomes. There was a significantly greater remineralisation post-erosion across three studies for all topical fluoride products compared to the placebo.

\section{Conclusion}

All the studies used human enamel that was subjected to erosive solutions before the removable appliances were inserted in the participants' mouths. This does not mimic what occurs in vivo during continuous erosive attacks. However, this was done in order to prevent demineralisation of the participants' teeth. There is a continuous ongoing cycle of demineralisation and remineralisation occurring after each acid attack. Saliva also plays a key role in preventing demineralisation of teeth by buffering the acidic conditions in the mouth.

The role of fluoride application in the prevention of enamel erosion is still controversial. The use of highly concentrated fluoride toothpastes, gels and varnishes has demonstrated the ability to increase enamel resistance to wear in in vitro and in situ studies only. However in vitro and in situ studies do not demonstrate the multiple acidic attacks experienced by teeth on a daily basis. Undertaking in vivo studies can be difficult due to the complexity of measuring erosive wear on human teeth in vivo.

With an ageing population retaining more teeth, dental erosion will become increasingly common and more difficult to treat. Current research suggests that topical fluoride does allow remineralisation of enamel, which will be beneficial in dental erosion. Unfortunately the literature appraised does not mention the effect topical fluoride has in preventing demineralisation as a result of erosion. Therefore further clinical studies need to be undertaken on this topic to allow clinicians to ascertain the best preventative treatment for their patients.

\section{Clinical bottom line}

Although the clinical evidence is limited, topical fluorides may still have a role to play in reducing dental erosion, as they can help remineralise enamel. Dental practitioners can help this process by applying topical fluoride varnish on teeth affected by erosion at recall appointments and ensuring patients use toothpastes containing fluoride. However dental practitioners must continue to educate their patients on the erosive affects of high dietary consumption of acidic food and drinks and the importance of optimal oral hygiene.

1. Magalhães AC, Wiegand A, Rios D, Honório HM, Buzalaf MA. Insights into preventive measures for dental erosion. / Appl Oral Sci 2009; 17: 75-86.

2. Steele J G, O'Sullivan I. Executive summary: Adult Dental Health Survey 2009. London: Health and Social Care Information Centre, 2010.

3. Lussi A, Hellwig E, Zero D, Jaeggi T. Erosive tooth wear: diagnosis, risk factors and prevention. $\mathrm{Am} /$ Dent 2006; 19: 319-325.

4. Maggio B, Guibert RG, Mason SC, et al. Evaluation of mouthrinse and dentifrice regimens in an in situ erosion remineralisation model. J Dent 2010; 38: Suppl 3: S37-44. doi: 10.1016/S0300-5712(11)70007-0.

5. Lussi A (ed). Dental erosion: from diagnosis to therapy. pp 3-5. Switzerland: Karger 2006.

6. Magalhães AC, Wiegand A, Rios D, Buzalaf MA, Lussi A. Fluoride in dental erosion. J Oral Sci; 2011; 22: 158-170.

7. Waszkiel D, Marczuk-Kolada G, Grądzka-Dahlkeb M Efficacy of fluoride varnishes in the prophylaxis of dental erosion. Res Rep Fluoride 2006; 39: 49-52.

8. Rees J, Loyn T, Chadwick B. Pronamel and tooth mousse: an initial assessment of erosion prevention in vitro. J Dent 2007; 35: 355-357.

9. Mathews M, Amaechi BT, Ramalingam K, et al. In situ remineralisation of eroded enamel lesions by NaF rinses. Arch Oral Biol 2012; 57: 525-530.

10. Vieira A, Jager DH, Ruben JL, Huysmans MC. Inhibition of erosive wear by fluoride varnish. Caries Res. 2007; 41: 61-67.

11. Ganss C, Neutard L, von Hinckeldey I, Klimek I, Schluete N.. Efficacy of a tin/fluoride rinse: a randomized in situ trial on erosion. J Dent Res 2010; 89: 1214-1218.

12. Magalhães A, Rios D, Martinhon CC, Delbem AC, Buzalaf MA, Machado MA. The influence of residua salivary fluoride from dentifrice on enamel erosion: an in situ study. Braz Oral Res. 2008; 22: 67-71.

Evidence-Based Dentistry (2013) 14, 59-62. doi:10.1038/sj.ebd.6400940. 